\title{
2-Hydroxy-4-lsopropoxy-5-bromoacetophenone Oxime as An Analytical Reagent for Palladium(II) Determination
}

\author{
A. M. DESAI \\ Sarvajanik College of Engineering \& Technology, Surat, India \\ ashishdesai76@gmail.com
}

Received 1 October 2013 / Accepted 8 November 2013

\begin{abstract}
Hydroxy-4-isopropoxy-5-bromoacetophenone oxime (HIBAO) has been synthesized and used as an analytical reagent for gravimetric and spectrophotometric determination of $\mathrm{Pd}(\mathrm{II})$. In $\mathrm{pH}$ range of 2.0 to 6.0 this reagent gives water insoluble yellow coloured complex with $\mathrm{Pd}(\mathrm{II})$. The reagent has been used for gravimetric determination of $\mathrm{Pd}(\mathrm{II})$. Interference of many cations and anions in gravimetric determination is studied for respective metals. Metal to ligand ratio of the complex has been determined using spectrophotometric methods. The stoichiometry of $\mathrm{Pd}(\mathrm{II})$ complex is 1:2 [M:L]. The complex obeys the Beer law up to $53.21 \mathrm{ppm}$ of $\mathrm{Pd}(\mathrm{II})$. The molar absorptivity and Sandell's sensitivity of the complex have also been calculated. The stability constant and Gibb's free energy change at $300 \mathrm{~K}$ are reported. Applicability of the reagent has been checked by determining palladium in palladised carbon. The IR spectra of ligand and complex has also been studied to establish the nature of linkage of metal ion with ligand.
\end{abstract}

Keywords: Oxime, Analytical reagent, 2-Hydroxy-4-isopropoxy-5-bromoacetophenone oxime, HIBAO, Palladium (II)

\section{Introduction}

In the current scenario of analytical chemistry, many organic reagents are widely used as analytical reagents. They include $o$-hydroxy ketoximes ${ }^{1-7}$, phenyl hydrazones, thiosemicar-bazones ${ }^{8-10}$, chalconeoximes $^{11}$ etc. These are generally used for spectrophotometric and gravimetric determination of transition metal ions. On reviewing literature, it was found that the bromo derivative of $o$-hydroxy ketoximes has not been used much. Further study of palladium(II) ion is less reported. With the introduction of bromine, the molecular weight of reagent is increased, which is expected to give advantage of higher conversion factor. Here we report the use of 2-hydoxy-4-isopropoxy-5-bromoacetophenone oxime as an analytical reagent for $\mathrm{Pd}(\mathrm{II})$.

\section{Experimental}

All the spectrophotometric work, $\mathrm{pH}$ measurements and elemental analysis were done on Shimadzu UV-160A, UV-Visible spectrophotometer, Equip-tronic pH meter (EQ-614) and Carlo Erba elemental analyzer respectively. Mettler electronic single pan balance AE-163 was used for weighing. The IR spectra were recorded on "Perkin-Elmer" FTIR Spectrophotometer (RX-1). 


\section{Synthesis of HIBAO}

Resacetophenone was synthesized from resorcinol, acetic acid and anhydrous zinc chloride according to the method of Robinson R and Shah R. $C^{12}$. 2,4-dihydroxy-5-bromoacetophenone was obtained by brominating resacetophenone with bromine in glacial acetic acid. 2-hydroxy4-isopropoxy-5-bromoacetophenone was prepared by condensation of 2,4-dihydroxy-5bromoacetophenone and isopropyl bromide in acetone and anhydrous potassium carbonate. The ketone was converted to oxime by usual method using hydroxylamine hydrochloride and sodium acetate. The oxime was recrystallised from ethanol. White coloured crystals with m.p. $195{ }^{\circ}$ C. (Nitrogen found: $5.02 \%$, Calculated :4.86\%)

\section{Results and Discussion}

\section{Gravimetric determination of Pd(II)-HIBAO complex}

A $0.04 \mathrm{M}$ solution of the reagent in $60 \%$ aqueous ethanol were used for gravimetric analysis of Pd(II). Palladium chloride $(0.01 \mathrm{M}, 20 \mathrm{~mL})$ solutions were taken in clean beakers and diluted to about $100 \mathrm{~mL}$ with distilled water and $\mathrm{pH}$ of the solutions were adjusted using suitable buffer. The solutions were warmed to $60{ }^{\circ} \mathrm{C}$ and a small excess of reagent $(0.04 \mathrm{M}$, $11 \mathrm{~mL}$ ) was added. The yellow coloured precipitate obtained were digested on water-bath for 60 minutes at $60{ }^{\circ} \mathrm{C}$. The precipitate were filtered through a previously weighed sintered glass crucible (G4) and washed with warm water followed by $60 \%$ aqueous ethanol to remove excess of the reagent which might have precipitated on dilution. The chelate was dried to constant weight at $110-115^{\circ} \mathrm{C}$ in hot air oven, cooled and weighed. The experiment was repeated with different aliquots, keeping the optimum $\mathrm{pH}$ to evaluate its applicability. The reagent works satisfactorily for gravimetric determination of $\mathrm{Pd}(\mathrm{II})$ in $\mathrm{pH}$ range 2.0 to 6.0. Error in any case did not exceed $\pm 1.0 \%$.

\section{Interference}

To study the effect of foreign ions in gravimetric determination, $810 \mathrm{mg}$ of various cations were added to solution containing $21.28 \mathrm{mg} \mathrm{Pd}(\mathrm{II})$ at $\mathrm{pH} 5.0$ and gravimetric estimations were done as described earlier. It was observed that cations like $\mathrm{Ca}(\mathrm{II}), \mathrm{Mg}(\mathrm{II}), \mathrm{Ni}(\mathrm{II})$, $\mathrm{Mn}(\mathrm{II}), \mathrm{Zn}(\mathrm{II}), \mathrm{Sr}(\mathrm{II}), \mathrm{Cd}(\mathrm{II}), \mathrm{Ba}(\mathrm{II}), \mathrm{K}(\mathrm{I})$ and $\mathrm{Na}(\mathrm{I})$ do not interfere at $\mathrm{pH} 5.0$ during the gravimetric analysis of $\mathrm{Pd}(\mathrm{II})$ but $\mathrm{Fe}(\mathrm{III}), \mathrm{Cu}(\mathrm{II}), \mathrm{Co}(\mathrm{II})$ and $\mathrm{V}(\mathrm{V})$ interfere seriously. Interference due to Fe(III) can be removed by masking with fluoride ion. Many common anions like chloride, bromide, iodide, nitrate, nitrite, sulphate were not found to interfere.

\section{Spectrophotometric study of Pd(II)-HIBAO complex}

It was found that $\mathrm{Pd}(\mathrm{II})$-HIBAO complex is soluble in ethyl acetate, chloroform and DMF. To have the absorption spectra, $5 \mathrm{mg}$ of complex was dissolved in $25 \mathrm{~mL}$ of ethyl acetate and absorption spectra of this solution was recorded in the wavelength range of $350 \mathrm{~nm}$ to $600 \mathrm{~nm}$. It was observed that the absorbance of the coloured solution of chelate increases continuously towards the shorter wavelength. All the measurements were carried out at $400 \mathrm{~nm}$.

To verify the Beer law different aliquots of $\mathrm{Pd}(\mathrm{II})$ solution $(0.005 \mathrm{M})$ were taken and buffer solution of $\mathrm{CH}_{3} \mathrm{COOH}+\mathrm{CH}_{3} \mathrm{COONa}$ was added to maintain $\mathrm{pH}$ 5.0. The excess of reagent $(0.01 \mathrm{M}, 6.0 \mathrm{~mL})$ was added to get precipitate of complex. It was extracted with three $5.0 \mathrm{~mL}$ portions of ethyl acetate and the combined extracts were diluted to $25 \mathrm{~mL}$. The absorbances of these solutions were measured at $400 \mathrm{~nm}$ against reagent blank. The absorbances were plotted against the concentration of $\mathrm{Pd}(\mathrm{II})$. It was found that Beer's law is obeyed up to $53.21 \mathrm{ppm}$ of Pd (II). The molar absorptivity and Sandell's sensitivity were 
calculated from Beer's law plot and were found to be $1.124 \times 10^{3} \mathrm{~L} \cdot \mathrm{mol}^{-1} \cdot \mathrm{cm}^{-1}$ and $0.095 \mu \mathrm{g}$ of $\mathrm{Pd}(\mathrm{II}) / \mathrm{cm}^{2}$ respectively. Job's ${ }^{13}$ and Mole-ratio ${ }^{14}$ methods were used to determine the stoichiometry of the complex. It was found to be 1:2 [M: L].

\section{Stability constants from Job's method and mole-ratio method}

The stability constants were calculated using the formula,

$$
\mathrm{Ks}=\frac{1-\alpha}{4 \alpha^{3} c^{2}} \quad \text { Where, } \quad \alpha=\frac{E_{m}-E_{s}}{E_{m}}
$$

Where, $\alpha=$ Degree of dissociation

$\mathrm{E}_{\mathrm{m}}=$ Maximum absorbance obtained at the intersect of the two lines.

$\mathrm{E}_{\mathrm{s}}=$ Absorbance at the stoichiometric molar ratio of the metal to ligand in complex. The average stability constant obtained from two methods is $9.54 \times 10^{9}$. From mean Ks value, the standard free energy change $\Delta \mathrm{G}^{0}$ at $300 \mathrm{~K}$ for the formation reaction of complex has been calculated using the formula.

\section{IR spectra}

$$
\begin{aligned}
\Delta \mathrm{G}^{0} & =-\mathrm{RT} \operatorname{lnKs} \\
& =-13.70 \mathrm{~K} \cdot \mathrm{cal} / \mathrm{mole}
\end{aligned}
$$

The IR spectrum (in $\mathrm{KBr}$ pellet) of ligand shows two bands for O-H stretching. One band at $3407 \mathrm{~cm}^{-1}$ is due to phenolic $2-\mathrm{OH}$ group and the other at $3300 \mathrm{~cm}^{-1}$ is due to oximino -OH group. A peak observed at $1636 \mathrm{~cm}^{-1}$ is due to the $>\mathrm{C}=\mathrm{N}$ stretching. A peak at $1221 \mathrm{~cm}^{-1}$ is due to C-O-C ether stretching. The peaks at $1028 \mathrm{~cm}^{-1}$ and $645 \mathrm{~cm}^{-1}$ are observed due to $\mathrm{N}-\mathrm{O}$ stretching and $\mathrm{C}-\mathrm{Br}$ stretching respectively. Examination of the IR spectra of the chelate shows that the band due to $\mathrm{O}-\mathrm{H}$ stretching of 2-hydroxy group disappears in a complex. This indicates that during chelate formation, the hydrogen of 2-hydroxy group is lost and oxygen forms covalent bond with metal. The absorption band observed due to $\mathrm{C}=\mathrm{N}$ stretching at $1636 \mathrm{~cm}^{-1}$ in ligand is shifted towards shorter wave number at about 1620 to $1625 \mathrm{~cm}^{-1}$ in the complex. This indicates that metal is coordinately bonded with nitrogen. This is also supported by slight downward shift of $v_{\mathrm{NO}}$ from $1028 \mathrm{~cm}^{-1}$ in ligand to $950 \mathrm{~cm}^{-1}$ in complex. The other bands due to oximino $\mathrm{O}-\mathrm{H}$ stretching, $\mathrm{C}-\mathrm{O}-\mathrm{C}$ ether stretching and $\mathrm{C}-\mathrm{Br}$ stretching observed in ligand are unaffected in spectrum of complex. Thus the comparison of IR spectra of ligand with that of complex indicates that metal is covalently bonded with oxygen and coordinately bonded with nitrogen of oximino nitrogen.

\section{Determination of palladium in palladised carbon}

The sample of palladised carbon $2.8466 \mathrm{~g}$ was weighed exactly and dissolved in concentrated nitric acid. The solution was heated to remove excess of acid and finally the solution was diluted to $250 \mathrm{~mL}$. $50 \mathrm{~mL}$ of the above solution was taken in a clean $250 \mathrm{~mL}$ beaker and palladium was determined gravimetrically using HIBAO as per the procedure described previously. The results were compared with the percentage of palladium determined using dimethyl glyoxime, a standard method to estimate palladium. Percentage of Pd found using HIBAO 4.95\% (Average of three determinations); Percentage of Pd found using DMG $4.92 \%$.

\section{Acknowledgement}

The authors are thankful to the Head, Chemistry Department, Veer Narmad South Gujarat University, Surat and Principal, Sarvajanik College of Engineering And Technology, Surat for providing the facilities to carry out the work. 


\section{References}

1. Singh Jai and Gupta S P, Indian J Chem., 1976, 14(A), 710.

2. Reddy K V and Paul Agnos, Indian J Chem., 1984, 23(A), 703.

3. Desai K K and Naik H B, Indian J Chem., 1986, 25-A, 297.

4. Jhaveri L C and Naik H B, J Indian Chem Soc., 1984, 61, 162.

5. Purohit Krishna and Desai K K, J Chem., 2005, 2(2), 161-164; DOI:10.1155/2005/825847

6. Shingadia S K and Desai K K, Chem., 2007, 4(1), 97-102; DOI:10.1155/2007/459181

7. Nair A P, Christine J and Desai K K, Oriental J Chem., 2008, 24(2), 693-696.

8. Reddy Hussain K and Prasad N B L, Indian J Chem, 2004, 43A, 111-115.

9. Sivaramaiah S, Reddy Raveendra P, Reddy Krishna V and Reddy Sreenivasulu T, Indian J Chem., 2003, 42A, 109-111.

10. Prasad N B L, Reddy Hussain K and Reddy Sreenivasulu T, Indian J Chem., 2003, 42A, 112-115.

11. Desai A M and Desai K K, Asian J Chem., 2004, 16(2), 1228-1230.

12. Robinson R and Shah R C, J Chem Soc, 1994, 1934

13. Job P M, Anal Chem., 1932, 4(3), 332-334; DOI:10.1021/ac50079a042

14. Yoe J H and Jones A L, Ind Eng Chem Anal Ed., 1944, 16, 111. 